\title{
STAN OCHRONY PRAW CZLOWIEKA Z PERSPEKTYWY RZECZNIKA PRAW OBYWATELSKICH
}

Stan ochrony praw człowieka w Polsce prawie 25 lat po odzyskaniu wolności i 26 lat od utworzenia urzędu Rzecznika Praw Obywatelskich wymaga uznania naszych polskich osiagnięć, ale i krytycznej refleksji. Jaki jest dziś właściwie stan naszej wolności i towarzyszących jej praw z perspektywy tego szczególnego organu kontrolującego władzę publiczna, jakim jest RPO?

W czasach ustrojowego przełomu lat dziewięćdziesiatych naturalny chaos wielkiej zmiany społecznej, nałożony zresztą na kiepską legislację przeszłości, wystarczająco usprawiedliwiał liczne niedomogi w działaniu władzy ustawodawczej $^{1}$ i wykonawczej ${ }^{2}$. Konieczność stworzenia szeregu regulacji od podstaw, potem ogromne tempo przystosowania do prawa europejskiego, wreszcie akcesja do Unii Europejskiej (a to wszystko w warunkach burzliwej walki politycznej) odpowiednio tłumaczyły wiele braków. Wspólnym wyjaśnieniem stale pozostawały „transformacja” i jej kłopoty ${ }^{3}$. Wystarczały one także jako tłumaczenie naszych dysfunkcji w skali międzynarodowej, np. wobec komitetów ONZ czy Rady Europy. Obecnie jednak możliwości takiego tłumaczenie się wyczerpują ${ }^{4}$.

${ }^{1}$ M. Krzyżanowska-Mierzewska, Dysfunkcje administracji publicznej $w$ Polsce $w$ orzeczeniach Europejskiego Trybunału Praw Człowieka, w: I. Lipowicz (red.), Europeizacja administracji publicznej. Zbiór studiów, Wyd. UKSW, Warszawa 2008, s. 117 i n.; P. J. Suwaj, Transformacja ustrojowa jako 'driving force' przemian administracji w krajach Europy Środkowej $i$ Wschodniej, „Administracja Publiczna. Studia Krajowe i Międzynarodowe” 2012, nr 2 (20).

${ }^{2}$ E. Knosala, A. Matan, G. Łaszczyca, Prawo administracyjne w okresie transformacji ustrojowej, Zakamycze, Kraków 1999.

${ }^{3}$ Por. A. Zieliński, Efektywność sqdowej ochrony wolności i praw jednostki w Polsce; M. Dybowski, Dysfunkcjonalność polskiego wymiaru sprawiedliwości oraz R. Bugaj, Ustrojowa transformacja polskiej gospodarki w latach 1990-2008, w: J. Kochanowski, M. Kuruś (red.), Quo vadis Polonia? W drodze do demokratycznego państwa prawa. Polska 1989-2009, Biuro RPO, Warszawa 2010; L. Kolarska-Bobińska, J. Kucharczyk, Demokracja w Polsce po dwudziestu latach przemian ustrojowych, w: iidem (red.), Demokracja w Polsce 2007-2009, Instytut Spraw Publicznych, Warszawa 2009.

${ }^{4}$ Raport Rzecznika Praw Obywatelskich z działalności w Polsce Krajowego Mechanizmu Prewencji w I kwartale 2012 r. dostępny na: http://www.brpo.gov.pl, Raport Europejskiego Komitetu ds. Zapobiegania Torturom oraz Nieludzkiemu lub Poniżającemu Traktowaniu albo Karaniu (CPT) w 2009 r.: http://ms.gov.pl/Data/Files/_public/foto/raport-cpt.pdf; zob. E. Dawidziuk, Traktowanie osób pozbawionych wolności we wspótczesnej Polsce na tle standardów międzynarodowych, Wolters Kluwer, Warszawa 2013; M. Krzyżanowska-Mierzewska, Kilka uwag o obecno- 
Byłoby logiczne (i optymistyczne) gdybyśmy w tej narracji - dokonanej już przecież - transformacji mogli dzisiaj stwierdzić, że co prawda pewne dysfunkcje nadal istnieja, ale jakość legislacji na poziomie ustawowym lub podustawowym stale się poprawia, a stwierdzone błędy stopniowo dotyczą kwestii coraz mniej ważnych z punktu widzenia praw człowieka. Tymczasem z perspektywy RPO, potwierdzonej w literaturze przedmiotu ${ }^{5}$, należy raczej odpowiedzieć na pytanie, czy możemy mówić już wręcz o „rozluźnieniu kanonów legislacji” i złudnym poczuciu, że przecież istnienie Senatu i Trybunału Konstytucyjnego zapewnia niezbędna, „ostateczną” korektę wadliwych aktów prawnych. Czy samo prawo i sposób jego stanowienia nie stały się źródłem naruszeń konstytucyjnych praw obywatelskich?

Działalność Rzecznika Praw Obywatelskich pozwala na specyficzna perspektywę tysięcy - w 2012 r. ponad 62 tys. - skarg obywateli ${ }^{6}$. Osoby zadowolone, pewne swoich praw oczywiście nie składają skarg, a więc dobre wykorzystanie prawa przez administrację nie zawsze być może jest właściwie docenione. Aby uwzględnić tę specyficzną „nierównowagę poznawczą, urząd Rzecznika Praw Obywatelskich dysponuje jednak systematycznymi badaniami własnymi, aktywną radą społeczną oraz komisjami ekspertów. Korzysta także z sygnałów mediów, wszczynając sprawy z urzędu ${ }^{7}$. Jednakże gdy setki skarg obywateli układają się w określona „matrycę”, staje się jasne, że to nie zaniedbanie, błędy lub arogancja pojedynczego pracownika administracji prowadzą do naruszenia praw człowieka, ale winna jest wadliwa legislacja generująca następne decyzje indywidualne bądź polityka publiczna dokonująca błędnej alokacji środków publicznych. Przykład to dyskryminująca norma o konieczności zapewnienia lub posiadania przez osobę niepełnosprawną odpowiednio dostosowanego pojazdu - choć szkoła jazdy ma obowiązek prawny posiadać odpowiednie urządzenia. W takim przypadku Rzecznik Praw Obywatelskich kieruje wystapienie generalne do odpowiedniego ministra. Jeżeli nie odnosi to skutku mimo naruszenia równości wobec prawa oraz postanowień ratyfikowanej ostatnio przez Polskę Konwencji o prawach osób niepełnosprawnych, pozostaje złożenie wniosku do Trybunału Konstytucyjnego ${ }^{8}$. Tak stało się także w tym przypadku.

ści Polski przed Europejskim Trybunałem Praw Człowieka w ostatnich latach, w: H. Machińska (red.), 60 lat Rady Europy. Tworzenie i stosowanie standardów prawnych, Oficyna Prawa Polskiego, Warszawa 2009.

${ }_{5}^{5}$ T. Zieliński, Ombudsman - możliwości i granice skutecznego działania, w: M. Zubik (red.), Księga XX-lecia Rzecznika Praw Obywatelskich w Polsce, t. 4, Warszawa 2008, s. 38 i n.

${ }^{6}$ Informacja o działalności Rzecznika Praw Obywatelskich w roku 2012 oraz o stanie przestrzegania wolności i praw człowieka i obywatela, Biuro RPO, Warszawa 2013.

${ }^{7}$ W 2012 r. było to odpowiednio 568 spraw (407 spraw podjętych do prowadzenia, 120 spraw podjętych w formie wystapienia generalnego, 41 innych spraw), zob. Informacja o dziatalności Rzecznika Praw Obywatelskich w roku 2012..., passim.

${ }^{8}$ Wniosek RPO do TK ws. stwierdzenia niezgodności ustawy o kierujących pojazdami (Dz. U. Nr 30, poz. 151 ze zm.) z Konstytucją w zakresie, w jakim nakłada na osoby niepełnosprawne 
Spróbujmy ukazać typowe przykłady stwierdzonych obecnie dysfunkcji. Przykładem prawa materialnego o wadliwej konstrukcji może być cała ustawa o kompensacie państwowej, w przypadku procedury należy sięgnać do procedury karnej, aby ukazać, jak można przez niewłaściwe jej ukształtowanie naruszyć prawa człowieka. Wymaga też podkreślenia kwestia braku ustawy reprywatyzacyjnej i ustawy o bezpłatnej pomocy prawnej oraz o mediacji (lub lepszego włączenia mediacji do istniejących aktów prawnych).

1. Zaczynając od procedury: panuje przekonanie, że w zakresie podstawowej procedury karnej od dawna jesteśmy „w Europie”. Tymczasem w sytuacji, w której prokurator odmówił wszczęcia postępowania w ważnej dla strony sprawie, a nie sporządził przy tym uzasadnienia (podobnie jak nie musi tego zrobić przy umorzeniu czy zawieszeniu postępowania), np. w sprawie śmiertelnego wypadku drogowego, widzimy poważne zagrożenie. Uważano początkowo, że sporządzanie takich uzasadnień jest oczywistościa, więc zbędne jest regulowanie tej kwestii, lecz zaniechanie uzasadnień okazało się często stosowane. Czy nie narusza to prawa strony do złożenia zażalenia? Zupełnie inaczej składa się przecież zażalenie, gdy znamy motywy postępowania danego prokuratora, a inaczej bez tej wiedzy. Zdumiewające jest tu swoiste „uprzywilejowanie" prokuratora przez ustawodawcę, być może przez zaufanie do jego poczucia obowiązku; jednak skoro z reguły zostało ono zawiedzione, normy wymagaja zmian. Postępowanie w takiej sprawie jest elementem prawa karnego, ale prokurator ustrojowo jest częścią administracji państwowej i obowiązuje go także w tym zakresie postulat dobrej administracji.

Kolejna kwestia to brak dostępu do akt postępowania karnego, np. dla rodzica osoby małoletniej zabitej w wypadku drogowym. Jeżeli rodzic nie został co się zdarza - dopuszczony do udziału w postępowaniu na prawach strony, nie ma także dostępu do akt sprawy. Z perspektywy RPO mamy wtedy do czynienia z naruszeniem sprawiedliwości - z punktu widzenia prawa pozytywnego, procedury karnej, wszystko jest „w porządku”: ustawa nie przewidywała po prostu takiej możliwości. Wybrano przykłady, w których bez głębokich analiz widoczna jest możliwość trwałego pokrzywdzenia strony w jej prawie do sprawiedliwego procesu i prawie do dobrej administracji ${ }^{9}$. Trudno też mówić o pogłębieniu w ten sposób zaufania do organów państwa.

Inny przykład - mimo głębokiego społecznego przekonania o niemal całkowitej liberalizacji przepisów paszportowych - wciąż brak sądowej kontroli nad

\footnotetext{
obowiązek dostarczania pojazdu przystosowanego do rodzaju schorzenia na potrzeby przeprowadzenia praktycznej części egzaminu państwowego sprawdzającego kwalifikacje osób ubiegających się o uprawnienia do kierowania pojazdami silnikowymi kategorii B, syg. RPO/658549/10/V/623.2 RZ, http://www.sprawygeneralne.brpo.gov.pl/pdf/2010/10/658549/1745109.pdf.

${ }^{9}$ Por. A. Pakuła, W kwestii zastosowalności europejskiego Kodeksu dobrej administracji $w$ funkcjonowaniu administracji publicznej $w$ Polsce, w: Z. Janku et al. (red.), Europeizacja administracji publicznej, Kolonia Limited, Wrocław 2005, s. 535; J. Świątkiewicz, Europejski Kodeks Dobrej Administracji, BRPO, Warszawa 2007.
} 
decyzją odmawiająca wydania dokumentu paszportowego (lub unieważniającą już wydany, w trybie administracyjnym), gdy chodziło o podejrzanego, wobec którego brak było zakazu opuszczania kraju. Tymczasem sądowa kontrola postępowania paszportowego należy do elementarnych wymagań procesowych $\mathrm{w}$ demokratycznym państwie prawnym ${ }^{10}$.

2. Tyle procedury, spójrzmy na prawo materialne: Czy za zgodna z zasadami sprawiedliwości społecznej możemy uznać sytuację, w której osoba skazana prawomocnym wyrokiem za molestowanie seksualne własnego dziecka żąda następnie po wielu latach alimentów od tego dorosłego już wówczas dziecka i pokrycia np. kosztów swojego pobytu w domu opieki? ${ }^{11}$ Prawo nie różnicuje zobowiązań alimentacyjnych dzieci wobec rodziców, więc te dorosłe dzieci muszą - tak jak dzieci np. agresywnych alkoholików i ojców, którzy porzucili swoje niepełnosprawne dziecko - po latach świadczyć na ich rzecz. Ustawodawca dał tu pierwszeństwo równości wobec zasady sprawiedliwości społecznej. Problem wymaga szerszej debaty społecznej, ale w przypadku ofiar orzeczonego kazirodczego molestowania seksualnego zmiana stanu prawnego wydaje się szczególnie uzasadniona ze względu na powrót dawnej traumy i głębokie naruszenie zasady sprawiedliwości. Postulowana zmiana prawa o pomocy społecznej nie została dokonana.

Zła jakość prawa materialnego może powodować namacalne, dramatyczne skutki społeczne, nawet jeżeli widoczne były początkowe dobre chęci ustawodawcy. Ten problem można ukazać z kolei na przykładzie istnienia izb wytrzeźwień ${ }^{12}$. Powszechnie były one krytykowane za - typowy dla tego swoistego ustrojowego reliktu poprzedniej epoki - prawie więzienny rygor, zwłaszcza za przypadki naruszeń praw człowieka, które wg badań Krajowego Mechanizmu Prewencji rzeczywiście się zdarzały ${ }^{13}$, i wymagaja przebudowy ich działania.

Wiele miast zdecydowało się więc na najprostsze rozwiązanie: likwidację izb wytrzeźwien, często z powołaniem na europejskie standardy ${ }^{14}$. Po likwidacji izb osoby nietrzeźwe, które zatrzymuje policja, ponieważ zagrażają sobie i innym osobom, są odwożone do szpitala lub na posterunek policji. W obu przypadkach te podmioty są na to nieprzygotowane: w izbach przyjęć nietrzeźwi

10 Wystapienie generalne RPO do Prokuratora Generalnego z 19 grudnia 2012 r., syg. RPO/668198/11/II/207.5RZ,http://www.sprawy-generalne.brpo.gov.pl/pdf/2011/02/668198/1690120. pdf.

11 Zob. wystapienie RPO do Ministra Pracy i Polityki Społecznej z 5 lutego 2014 r. ws. zagwarantowania należytej ochrony członkom rodziny zobowiązanym do ponoszenia opłaty za pobyt mieszkańca w domu pomocy społecznej.

$12 \mathrm{O}$ izbach wytrzeźwień piszę szerzej w: Izby wytrzeźwień w perspektywie Rzecznika Praw Obywatelskich, w: T. Gardocka, J. Sobczak (red.), Izby wytrzeźwień a prawa człowieka, Wydawnictwo Adam Marszałek, Torun 2013, s. 150 i n.; por. J. Zagórski, Podstawy prawne działalności izb wytrzeźwień w Polsce, „Państwo i Prawo” 2005, z. 12, s. 80-92.

${ }^{13}$ Raport Rzecznika Praw Obywatelskich z wizytacji w izbach wytrzeźwień przeprowadzanych przez Krajowy Mechanizm Prewencji, BRPO, Warszawa, lipiec 2013; zob. także J. Kołtun, Izby wytrzeźwień a prawa człowieka w kontrolach NIK, w: T. Gardocka, J. Sobczak (red.), op. cit., s. 150 i $\mathrm{n}$.

${ }_{14}$ M. K. Jeleniewski, Społeczne konsekwencje likwidacji izby wytrzeźwień w Bydgoszczy, w: T. Gardocka, J. Sobczak (red.), op. cit., s. 184 i n. 
stają się postrachem, zwłaszcza nocnych izb przyjęć - zagrażają sobie, innym pacjentom, czasem lekarzom, a brak wciąż specjalistycznych procedur działania i wyspecjalizowanych w tym zakresie oddziałów szpitalnych. Jeszcze trudniej jest w przypadku posterunków policji $\left(\mathrm{PdOZ}^{15}\right)$ - tu brak lekarza i trudność oceny rzeczywistego stanu osoby nietrzeźwej powodują liczne przypadki śmiertelne, które budzą najwyższe zaniepokojenie RPO oraz krytykę ze strony organów $\mathrm{ONZ}^{16}$. W istocie przyczyną udręki społecznej jest ułomna regulacja. Jest oczywiście rzeczą parlamentu rozstrzygnięcie, czy powinny to być wyspecjalizowane oddziały szpitalne (co wymaga odpowiednich zmian prawa materialnego z zakresu ochrony zdrowia), czy też dawne izby wytrzeźwień powinny stać się - co uważam za optymalne - częścią nowoczesnych wielofunkcyjnych centrów terapii uzależnień, jak się to od lat dzieje (na podstawie inicjatywy samorządowej) w Bytomiu, Olsztynie czy Kaliszu ${ }^{17}$. Nowa regulacja jest tutaj niezbędna, gdyż dotychczasowa prowadzi do naruszenia praw człowieka.

W każdym razie wszystkie te rozwiązania są lepsze niż obecny stan dysfunkcji. Co interesujace, nie jest to nawet (co bardzo rzadkie) kwestia finansowa: fundusz przeciwalkoholowy stanowiący część dochodów - tzw. korkowe jest w opinii NIK $^{18}$ w ok. 50\% wydawany niezgodnie z przeznaczeniem, a więc zmiana może się dokonać nawet bez szkody dla dotychczasowych, o ile tylko są sensowne, przedsięwzięć finansowanych z Funduszu. Obecny stan zagraża natomiast również funkcjonariuszom policji obarczonym odpowiedzialnościa za zatrzymanego nietrzeźwego przy braku rzetelnej możliwości zapewnienia właściwej opieki lekarskiej ${ }^{19}$. Z drugiej strony organizatorzy masowych imprez sportowych nie są wcale obciazzani obowiązkiem tworzenia dobrowolnych „miejsc trzeźwienia” kibiców na własny koszt, jak było to podczas EURO $2012^{20}$, ale tylko w związku z żądaniami UEFA. Odciążyłoby to zarówno policję, jak i budżet i przywróciło sprawiedliwe proporcje. Podstawowy jest jednak fakt, że w obecnej sytuacji nietrzeźwi ludzie, którzy znajdowali się przymusowo pod pieczą państwa, częściej niż poprzednio ponoszą śmierć, a to państwo przecież od momentu ich zatrzymania przyjmuje na siebie obowiązek strzeżenia ich życia i zdrowia.

15 Pomieszczenie dla osób zatrzymanych, zob. więcej: Monitoring wizyjny $w$ miejscach pozbawienia wolność. Raport Krajowego Mechanizmu Prewencji, BRPO, Warszawa 2012.

${ }^{16}$ Wystapienie generalne RPO do Ministra Spraw Wewnętrznych z 18 lipca 2013 r., syg. RPO/690709/11/II/715 RZ, http:/www.sprawy-generalne.brpo.gov.pl/pdf/2011/12/690709/1737890. pdf, a także wystapienie generalne RPO do Komendanta Głównego Policji z 22 marca 2013 r., syg. RPO/690709/11/II/715 RZ, http://www.sprawy-generalne.brpo.gov.pl/pdf/2011/12/690709/1710641. pdf.

17 T. Gardocka, J. Sobczak (red.), op. cit., s. 18, a także s. 151.

18 Wyniki kontroli Najwyższej Izby Kontroli ws. realizacji i wykorzystania przez samorządy województw i gmin dochodów z opłat za korzystanie z zezwoleń na sprzedaż napojów alkoholowych, http://bip.nik.gov.pl/kontrole/wyniki-kontroli-nik/kontrole,10553.html, a także zestawienie statystyczne dot. profilaktyki i rozwiązywania problemów alkoholowych w Polsce w samorządach gminnych w 2012 r. dostępne na stronie internetowej Państwowej Agencji Rozwiązywania Problemów Alkoholowych, http://www.parpa.pl/images/file/Zestawienia_statystyczne_2012.pdf.

${ }_{19}$ Raport RPO z działalności w Polsce Krajowego Mechanizmu Prewencji w 2012 r., http:// www.rpo.gov.pl/sites/default/files/raport_kmp_2012.pdf, s. 67 i n.

${ }^{20}$ Zob. http://wyborcza.pl/1,76842,11873860,Polowe_izby_wytrzezwien_na_Euro.html. 
3. W przypadku luki prawnej w postaci braku ustawy reprywatyzacyjnej należy pamiętać, że ustawa taka była już ogromnym wysiłkiem legislacyjnym uchwalona ${ }^{21}$, lecz została zawetowana przez prezydenta ${ }^{22}$. Udaremniło to także intensywne prace ekspertów i doktryny ${ }^{23}$. Aktywność sądów wypełniła następnie częściowo „pusty” obszar, ale nastapiło to ze szkodą dla równości wobec prawa i jednolitości rozstrzygnięć. Wskazywała na to już Teresa Rabska, stwierdzając: „[...] Bardzo więc źle się stało, że proces reprywatyzacji i tak już bardzo spóźniony - nie został na drodze generalnych uwarunkowań wszczęty. Braku ustawy nie zastapi dochodzenie w trybie indywidualnym, drogą sądowa, utraconego majątku. Tych dwóch zasadniczo różnych dróg przywracania prawidłowego stanu prawnego - w indywidualnym trybie sądowym i generalnym ustawowy - nie można traktować zamiennie"24. Przewidywania te w pełni się sprawdziły. Istotnie obecna sytuacja, jak pisała autorka: „podważa zaufanie do prawa pozbawionego odpowiednich regulacji”. Kolejne parlamenty nie poradziły sobie z tym zadaniem w kolejnych kadencjach. W sytuacji braku systemu bezpłatnej pomocy prawnej zubożali dawni właściciele, przez lata - w sytuacji tak złożonego i niepewnego stanu prawnego - bezskutecznie dochodzą swoich praw, podczas gdy inni uprawnieni zrealizowali swoje roszczenia w stosunkowo krótkim czasie. Pojawiła się też grupa agresywnie działających na rynku podmiotów, zawodowo skupujących za niewielką cenę roszczenia i sprawnie usuwających mieszkańców nieruchomości bezprawnymi działaniami ${ }^{25}$.

Podwójnie poszkodowane sa gminy - zaskakiwane jak Warszawa ${ }^{26}$ czy Gdynia skalą wysokości odszkodowań i koniecznością szybkiego znalezienia

${ }^{21}$ Zob. przebieg procesu legislacyjnego dla rządowego projektu ustawy o reprywatyzacji nieruchomości i niektórych ruchomości osób fizycznych przejętych przez Państwo lub gminę miasta stołecznego Warszawy oraz o rekompensatach (druk nr 1360): http://orka.sejm.gov.pl/proc3.nsf/ opisy/1360.htm.

${ }^{22}$ Zob. decyzja Prezydenta RP A. Kwaśniewskiego ws. ustawy reprywatyzacyjnej: http:// www.prezydent.pl/archiwum/archiwum-aktualnosci/rok-2001/art,157,15,decyzja-prezydenta-rp-w-sprawie-ustawy-reprywatyzacyjnej.html.

${ }^{23}$ Por. opinie dla BAS do druku sejmowego nr 1360 z dnia 20 września 1999 r.: T. Rabska, Opinia prawna dotyczaca projektu ustawy o reprywatyzacji i rekompensatach (druk nr 1360), a także A. Patrzałek, Opinia w sprawie zgodności z Konstytucją RP z 2 kwietnia 1997 r. art. 8 ust. 1 projektu ustawy o reprywatyzacji nieruchomości i niektórych ruchomości osób fizycznych przejętych przez Państwo lub gminę m.st. Warszawy oraz o rekompensatach (druk 1360); M. Granat, Opinia w sprawie zgodności z art. 8 ust. 1 projektu ustawy o reprywatyzacji nieruchomości i niektórych ruchomości osób fizycznych przejętych przez Państwo lub gminę m.st. Warszawy oraz o rekompensatach; M. Górski, Opinia w sprawie relacji prawnych pomiędzy projektami ustaw z druków nr 1360 i nr 1455.

${ }^{24}$ T. Rabska, Rozważania nad ustrojowoprawnymi podstawami reprywatyzacji, w: S. Fundowicz, F. Rymarz, A. Gomułowicz (red.), Prawość i godność. Księga pamiatkowa w 70. rocznice urodzin Profesora Wojciecha Eqczkowskiego, Lublin 2003.

${ }_{25}$ Szerzej o fundamentalnych kwestiach reprywatyzacji: W. Łączkowski, Ustrojowe podstawy reprywatyzacji w III Rzeczypospolitej polskiej, w: Reprywatyzacja w systemie prawa, Wydawnictwo Senatu RP, Warszawa 1999, s. 27 i n.

${ }^{26}$ Nowelizacja ustawy o komercjalizacji i prywatyzacji (Dz. U. 2013, poz. 1643) wprowadziła dotację celową na zaspokajanie odszkodowań dla byłych właścicieli nieruchomości znacjonalizowanych na podstawie tzw. dekretu Bieruta. O taką dotację może ubiegać się m.st. Warszawa przez trzy lata (2014-2016), a dofinansowanie w każdym roku budżetowym nie może przekroczyć 200 mln. 
mieszkań socjalnych dla (często sędziwych) lokatorów zmuszonych do szybkiej wyprowadzki. Mimo że samorządowi przysługuje konstytucyjna gwarancja samodzielności, jest on w istocie bezbronny wobec bezczynności ustawodawcy w tak ważnej sprawie społecznej. Państwo ugina się pod ciężarem wypłaconych odszkodowań, choć w pełni zrozumiała (również w skali międzynarodowej) byłaby ustawa miarkująca odszkodowania z tego tytułu. Komplikująco działają oczywiście możliwe implikacje międzynarodowe, ale i one sa przecież możliwe do rozwiązania i od dawna posiadają obfitą literaturę, jak i orzecznictwo ${ }^{27}$.

Jak ma się zachować obywatel bezsilny wobec bezczynności władzy ustawodawczej i wykonawczej w najbardziej istotnej dla niego sprawie życiowej nagłej utraty jego mieszkania? Ustawodawca stale zaostrza odpowiedzialność materialną urzędników państwowych, brak natomiast - poza komisjąetyczna_jakiejkolwiek ścieżki wewnętrznej odpowiedzialności za generowanie przez parlament prawa złej jakości. Współcześnie wywodzi się legitymację demokratyczną również z efektywności sprawowania władzy ${ }^{28}$. Na tym założeniu oparte jest m.in. prawo do dobrej administracji. Chociaż w przypadku wadliwej legislacji rangi podustawowej i ustawowej pozostaje nam oczywiście Trybunał Konstytucyjny, to i on jest jednak bezsilny w przypadku całkowitego zaniechania ustawodawcy. Kwestia reprywatyzacji jest przy tym tak złożona, że brak jest możliwości powodzenia jakiejkolwiek inicjatywy obywatelskiej, a nawet indywidualnego projektu poselskiego.

Prawa człowieka wzbogaciły krajowy system o konwencje Rady Europy, które po ratyfikacji mają swoje ustalone miejsce w systemie źródeł prawa, ale bardziej efektywne jest w ich „wymuszaniu” lub zastępowaniu brakujacej regulacji unijne prawo europejskie. To ono bowiem generuje jak dotychczas jedyne konkretne sankcje za bezczynność państw członkowskich.

Zaniechania parlamentu, trwajace przez lata, powodują nieuzasadnione wzbogacenie jednych podmiotów, a pokrzywdzenie innych, generuja niepewność, a często (jak w Poznaniu) także przemoc wobec lokatorów reprywatyzowanych kamienic. Czasem zresztą bezczynność władzy ustawodawczej splata się z bezczynnością władzy wykonawczej. Właśnie prokuraturze poznańskiej można przypisać głośną odmowę interwencji zgodnie z przekonaniem, że działanie nowych właścicieli powodujących liczne udręki: celowe zalewanie mieszkań fekaliami, wyłączenie prądu i ogrzewania to tylko „przemoc wobec rzeczy”, a nie wobec ludzi. Wymaga się więc długotrwałego procesu cywilnego na koszt lokatorów, bardzo często osób starszych i bezrobotnych. Procesu, który jest konieczny, aby przywrócić np. dostawę wody lub odprowadzenie ścieków, czego nie może w obecnym stanie prawnym wymusić nawet nadzór budowlany - podłączenie ponowne instalacji nie oznacza, że będzie w niej płynąć woda.

${ }_{27}$ Zob. artykuł prasowy pt.: 200 mln dla Warszawy na odszkodowania już dostepne, „Dziennik Gazeta Prawna” z 2 stycznia 2014 r., nr 1.

28 Szerzej o legitymacji demokratycznej piszę w rozdziale Legitymacja demokratyczna; efektywność i akceptacja jako źródła legitymacji administracji, w: Z. Niewiadomski (red.), Prawo administracyjne, LexisNexis, Warszawa 2013. 
Może więc powstać trwałe naruszenie sprawiedliwości społecznej w wyniku bezczynności prawodawcy. Najbardziej jaskrawe są skutki dla obu stron procesu reprywatyzacji - zarówno właścicieli odzyskiwanych (lub nie) kamienic, jak i ich mieszkańców. Ustrojodawca wprowadził zasadę demokratycznego państwa prawa, a w tym poszanowanie prawa własności. Oznaczało to, że tysiące właścicieli skonfiskowanych przed laty nieruchomości mogą dążyć do odzyskania własności. Przez 10-20 lat próbują odzyskać swoje nieruchomości, a ich dotychczasowi mieszkańcy żyją latami w niepewności. Zwykle po odzyskaniu nie są zdolni ich utrzymać, a podmioty, które przejmują nieruchomości, eksmitują mieszkańców. Niektórzy czynią to jeszcze z poszanowaniem praw człowieka, inni - brutalnie stosując przemoc pośrednią. Poszkodowane są także gminy, zaskakiwane rozmiarem odszkodowań orzekanych przez sądy i bez przygotowanych mieszkań socjalnych ${ }^{29}$. Bezczynność władzy ustawodawczej prowadzi do trwałego pokrzywdzenia stron postępowania, a Trybunał Konstytucyjny nie jest $\mathrm{w}$ stanie wymusić działania ustawodawcy w warunkach jego całkowitej bierności.

4. Najbardziej jednak jaskrawym przykładem całkowicie dysfunkcyjnej, w płaszczyźnie ustrojowej, materialnej i procesowej regulacji jest ustawa o kompensacie państwowej ${ }^{30}$. To przykład szczególny, łączy się bowiem od początku z fałszywym wyborem metody regulacji (zamiast prawa administracyjnego - prawo cywilne), z wszelkimi możliwymi błędami.

Spróbujmy ukazać, jakie skutki pociaga za soba taki fałszywy wybór: w ustawie chodzi o doraźne poprawienie sytuacji osób, które stały się ofiarami ciężkich przestępstw przeciwko życiu lub zdrowiu, a sprawca (np. narkoman lub alkoholik) nie posiada żadnego majątku, z którego można by zaspokoić w przyszłości uzasadnione roszczenia ofiary o pokrycie kosztów np. leczenia czy rehabilitacji. Państwo przeznaczyło, wykonując dyrektywę Unii Europejskiej, w tej sytuacji do 12 tys. zł od osoby na pokrycie takich roszczeń. Zamiast jednak wypłacać po wiarygodnym stwierdzeniu faktów te środki (np. w trybie pomocy społecznej), skonstruowano specyficzny tryb postępowania, w którym centralną rolę odgrywa prokurator, i to zorientowany głównie na zapobieganie wyłudzeniu środków publicznych ${ }^{31}$. Ofiara przestępstwa jeszcze raz podlega „przesłuchaniom”, zdarzało się nawet, że ofiara ciężkiego pobicia była konfrontowana ze sprawca, a następnie - po trudnym dla niej psychologicznie postępowaniu - odmawiano jej np. ze względów formalnych pomocy, a ponadto w końcu obciążono kosztami sądowymi. To sprawia, że z tak skonstruowanej procedury skorzystało - zamiast prognozowanych tysięcy - kilkadziesiąt osób.

Nie świadczy najlepiej o naszym systemie prawa i doktrynie to, że do stworzenia systemu kompensacyjnego zobowiązała Polskę dopiero dyrektywa

\footnotetext{
${ }^{29}$ Zob. http://prawo.gazetaprawna.pl/artykuly/425947,eksmisje_gminy_sa_pozostawione_same_ sobie.html.

${ }^{30}$ Ustawa z 7 lipca 2005 r. o państwowej kompensacie przysługującej ofiarom niektórych przestępstw umyślnych, Dz. U. 2005, Nr 169, poz. 1415 ze zm.

${ }^{31}$ L. Mazowiecka, Wyniki badań nad funkcjonowaniem ustawy o kompensacie państwowej, w: eadem (red.), Kompensata państwowa dla ofiar przestepstw w Polsce. Teraźniejszość i przyszłość, Warszawa 2013, s. 59 i n.
} 
Rady z 29 kwietnia 2004 r., która wprowadziła zresztą głównie transgraniczny system współpracy pomocy ofiarom przestępstw ${ }^{32}$. Wydawałoby się, że Polska wzorowo wdrożyła dyrektywę, ponieważ nasza ustawa weszła w życie istotnie w 2005 r., a jej cel był identyczny: łagodzenie wiktymizacji pierwotnej. Ustawodawca, tworząc ten akt normatywny, zakładał, że skorzysta z niego rocznie ok. 12800 osób. Tymczasem ustawa ta stała się praktycznie „ustawa jednego przypadku”, a właściwie 43 przypadków, ponieważ tyle osób rocznie z niej korzysta ${ }^{33}$. Skoro zaplanowano ok. 13000 osób, a każda z nich może otrzymać wsparcie finansowe w wysokości ok. 12 tys. zł, łatwo policzyć, jakie środki musiano zabezpieczyć w budżecie państwa na ten ważny aspekt ochrony praw człowieka - środki te nie zostały wykorzystane zgodnie z przeznaczeniem i stały się „oszczędnościa” resortu.

Kompensata dla ofiar przestępstw była przedmiotem rezolucji Rady Europy z 28 września 1977 r. (77) 27, a 24 listopada 1983 r. została uchwalona Europejska konwencja o kompensacji dla ofiar przestępstw popełnionych z użyciem przemocy, której Polska do dzisiaj nie podpisała ani nie ratyfikowała ${ }^{34}$.

Jakie podstawowe dysfunkcje wykazuje ta pośpiesznie uchwalona ustawa? Wstępnie można stwierdzić tylko, że jeżeli zastępca prokuratora generalnego stwierdza oficjalnie: „naprawdę trudno zrozumieć, jaką rolę odgrywa prokurator w postępowaniu kompensacyjnym", to trudno o lepsze wprowadzenie do tej nieudanej ustawy. Nie zmieniły przy tym sytuacji wytyczne z 21 grudnia 2011 r., które nakazywały analizę akt postępowań karnych pod kątem możliwości skorzystania z kompensaty dopiero od 2011 r. ${ }^{35}$ Mimo to nie nastapiła żadna zmiana sytuacji w ilości osób, którym udzielono pomocy, nie osiagnięto też w żaden sposób efektu „ograniczenia niesprawiedliwości”, który miał być celem działania ustawy, mimo że stopniowo wzrasta wysokość odszkodowań. Należy ukazać systematycznie przejawy dysfunkcji omawianej ustawy, która jest prezentowana jako wdrożenie dyrektyw. Po pierwsze - już twórcy projektu ustawy wadliwie, sprzecznie z art. 18 dyrektywy, określili termin utworzenia systemu kompensaty. Dopiero po interwencji RPO przywrócono właściwy termin - 1 lipca 2005 r., ponieważ Komitet Integracji Europejskiej zignorował tę różnicę. Sprzeczność z dyrektywą utrzymuje się nadal, również kolejny prosty błąd legislacyjny sprawia, że nie można mówić o prawidłowym jej wdrożeniu: ustawodawca - jak wskazano w literaturze - wbrew treści dyrektywy uczynił te same organy organami orzekajacymi i pomocniczymi we wszystkich sprawach kompensacyjnych, co sprawia, że po prostu nie ma organu właściwego do orzekania w sprawach transgranicznych ${ }^{36}$. Paradoksalnie

${ }^{32}$ Dyrektywa Rady 2004/80/WE z 29 kwietnia 2004 r. odnosząca się do kompensaty dla ofiar przestępstw, Dz. Urz. UE L 261 z 6 sierpnia 2004 r.

${ }^{33}$ S. Łagodziński, Praktyka przyznawania świadczeń z ustawy z dnia 7 lipca 2005 r. o państwowej kompensacie przystugujacej ofiarom niektórych przestepstw, Instytut Wymiaru Sprawiedliwości, Warszawa 2011.

${ }^{34}$ L. Mazowiecka, Państwowa kompensata dla ofiar przestęstw, Wolters Kluwer, Warszawa 2012, s. 52 i n.

${ }^{35}$ Por. projekt ustawy z 3 września 2009 r./ Opinia z 30 maja 2005 r.

36 E. Bieńkowska, C. Kulesza, Państwowa kompensata dla ofiar przestepstw. Geneza, znaczenie i standardy ksztattowania instytucji, w: L. Mazowiecka (red.), op. cit., s. 44. 
ten błąd przeniesiono w 2009 r. w nowelizacji, która miała poprawić jaskrawe błędy legislacyjne z 2005 r. Przykładem takiego błędu z 2005 r. było użycie przesłanki obywatelstwa w sytuacji, gdy dyrektywa wręcz w tytule używa przesłanki stałego miejsca zamieszkania: naprawdę, trudno było to przeoczyć. W rezultacie mamy nową przesłankę dyskryminacji. Imigranci mający prawo stałego zamieszkania na terenie Unii Europejskiej, a niebędący jej obywatelami (np. uchodźcy polityczni), jeżeli staną się ofiarą przestępstwa np. napadu - sa pozbawieni prawa do kompensaty ${ }^{37}$, która w ich przypadku byłaby szczególnie potrzebna.

Oto dalsze przykładowe błędy: wybrany jako organ pomocniczy prokurator okręgowy jest zbyt oddalony od miejsca przestępstwa. Może oczywiście delegować prokuratora rejonowego, ale strona - pokrzywdzony musiałaby o tym najpierw w ogóle wiedzieć, a krótkie terminy to praktycznie uniemożliwiaja. W dodatku ustawodawca wtrąca obywatela w osobliwą pułapkę: może zaryzykować postępowanie cywilne w sprawach kompensaty, ale nie wie z góry, czy sprawca napadu (np. narkoman) nie zostanie uznany za niepoczytalnego, wtedy - ponieważ ustawodawca mylnie powiązał kompensatę z konstrukcją winy nie tylko nie otrzyma pieniędzy (nie jest to przecież odszkodowanie), ale w dodatku zostanie obciążony kosztami sądowymi. W wystapieniach Rzecznika często pojawia się stwierdzenie, że prawo nie powinno stanowić takiej klasycznej „pułapki dla obywatela”. Ukoronowaniem nieudolnego działania było opublikowanie przez prokuraturę zbyt złożonej informacji dla ofiar pozbawionej spisu treści. W pouczeniu dla ofiar znajdujemy odwołanie się do ustawy z 2005 r., ale jest to wiadomość tak trudna do odkodowania bez fachowej pomocy prawnej, zwłaszcza w sytuacji braku systemu bezpłatnej przedsadowej pomocy prawnej i tego, że głównym adresatem są osoby niezamożne, że czyni to ten akt fasadowym. Kompletna blokada dotyczy natomiast praw do kompensaty imigrantów bez obywatelstwa polskiego lub Unii Europejskiej.

Klasycznym przykładem generowania sprzecznych sygnałów wobec adresata normy może być art. 5 i 7 ustawy. Najpierw zapewniamy ofiarę, że kompensata zostanie przyznana „niezależnie od tego, czy sprawca (lub sprawcy) zostali wykryci, oskarżeni lub skazani” (art. 5), aby potem w art. 7 ust. 2 dodać, że jednak jej nie przyznamy, jeżeli... i tu następuje pięć przesłanek (pkt 1, 2, 3, 7, 9), np. brak skargi uprawnionego oskarżyciela - w szczególności nastapi odmowa: „gdy umorzy się postępowanie karne w przypadku działania przez sprawcę w błędzie lub jego uniewinnienie" - na co ofiara nie ma wpływu ${ }^{38}$.

Zdumiewające jest w końcu uznanie tak mozolnie uzyskanego świadczenia za odszkodowanie i zaordynowanie nieprocesowego postępowania cywilnego. To obciąża wnioskodawcę kosztami wstępnymi i plasuje nas znowu blisko kategorii winy, na której przecież kompensata nie jest oparta. W dodatku - jak wskazuja Ewa Bieńkowska i Cezary Kulesza - to postępowanie może w każdej chwili przekształcić się w uciążliwy proces ${ }^{39}$. Skąd w jednym akcie aż tyle

37 Ibidem, s. 45.

38 C. Kulesza, Rola pokrzywdzonego w procesie karnym, Białystok 1995.

${ }^{39}$ E. Bieńkowska, C. Kulesza, op. cit., s. 44 i n. 
błędów i nieudolności? Nie było - jak sądzę - u źródeł legislacji rzeczywistej chęci pomocy ofiarom. Ustawa została wymuszona przez dyrektywę, źle przygotowana i przyjęta - z błędami - w ostatniej chwili. Nie miała oparcia, jak w innych krajach, w Konwencji, a w dodatku próbowano - fatalnie od strony techniki legislacyjnej - ograniczyć prawa ofiary jak to tylko możliwe, w imię prawdopodobnych oszczędności budżetowych i z lęku przed udzieleniem pomocy w sposób nadmierny. Ponieważ nie dało się z niej skorzystać, pozostawione środki stały się cichą rezerwą budżetową.

Charakterystyczna jest $\mathrm{w}$ tym kontekście opinia sędziów stosujących ustawę - dodaja oni jeszcze nowe trudności związane z jej stosowaniem: np. brak określenia, kto ponosi koszty tłumaczenia, kwestia udziału sprawcy w postępowaniu (skoro to od niego żądać się będzie regresu), choć udział ten z kolei dodatkowo odstrasza ofiarę od skorzystania ze swego prawa. Ustawa ta jest modelowym przykładem nieudolności prawodawcy, który podtrzymywał przez lata jej błędy, niezależnie od zmieniających się rządów.

Twórcy projektu ustawy mieli przecież świadomość, że większość spraw karnych, w których ofiara przestępstwa doznaje „naruszenia czynności narządów ciała” lub „rozstroju zdrowia” w sposób przynajmniej uprawdopodabniający wypłatę kompensaty, toczy się na szczeblu prokuratury rejonowej, a nie okręgowej - a mimo to ulokowano kompetencje na niewłaściwym szczeblu, naruszając postanowienia dyrektywy. Ponadto skoro podstawa przyznania kompensaty jest samo wystapienie czynu bezprawnego i poniesienie szkód nie tylko przez osobę uprawnioną lub osobę najbliższa, jak można było dopuścić do regulacji, w której - np. w przypadku utraty w wyniku przestępstwa osoby najbliższej i otrzymania kompensaty - trzeba będzie ją zwrócić, gdy sprawca okaże się ostatecznie niepoczytalny. Nie chodzi więc już nawet o - dla niektórych ofiar i tak zaporowa - wstępną opłatę w wysokości 40 zł (tytułem opłaty od wniosku o przyznanie kompensaty), ale o wiele gorsze perspektywy poniesienia kilku tysięcy złotych kosztów sądowych lub zwrotu całej sumy z przyczyn zupełnie niezależnych od ofiary przestępstwa. Cała struktura postępowania skutecznie uniemożliwia zreszta skorzystanie z kompensaty np. ofiarom handlu ludźmi lub osobie tak ciężko poszkodowanej, że w krótkim terminie przeznaczonym na wniosek nie mogła z niego skorzystać, a rodzina ofiary pozbawiona jest w ustawie odpowiednich uprawnień.

Jakie kwoty po tym uciążliwym, nieprzyjaznym adresatowi normy, postępowaniu w ogóle przyznano? Niewidomej ofierze przestępstwa - 129 zł $60 \mathrm{gr}$, złamanie kości czaszki i utrata zębów - 6600 zł, ale ofierze, która nie ma już kości czaszki, a tylko skórę i nie przeżyje bez leków, przyznano 1400 zł - sąd stwierdził: „niedostateczny dowód istniejących kosztów rehabilitacji”. Aby pozostać tylko przy urazach głowy: za złamanie w wyniku przestępstwa kości ciemieniowej, skroniowej i klinowej oraz krwiaka mózgu dziecka - 770 zł w pierwszej instancji (ze względu na brak rachunków za jogurty, biszkopty i zupy, którymi wyłącznie można odżywiać teraz ofiarę), w drugiej instancji to już 4130 zł. Sądy - jak wskazują badania Lidii Mazowieckiej - skupiały się na egzekwowaniu rachunków za bilety, wody mineralne, owoce i kaszki, choć zszokowane rodziny ofiar raczej nie gromadziły ich w pierwszej fazie ratowa- 
nia życia ofiary i opieki szpitalnej. Tym zarzutem nie trzeba już obciążać ustawodawcy - sąd ma cały czas do dyspozycji art. 322 k.c., który pozwala odstapić od żądania rachunków w takiej sytuacji, ale tego nie czynił.

Analizowana ustawa wygląda tak, jakby ambicja jej twórców było zawarcie w jednym akcie wszystkich możliwych nieprawidłowości. Mamy więc tutaj także dodatkowo dyskryminację osób ubogich - ponieważ ważne są wydatki już poniesione i przedłożone rachunki, w lepszej sytuacji są więc osoby, które w ogóle były w stanie te wydatki z własnych środków ponieść, a więc zamożniejsze. Wtedy można za implant jednego zęba otrzymać nawet $10000 \mathrm{zł}$, choć rachunek opiewał na 5000 zł. W świetle ustawy prawa do kompensaty nie ma przy tym osoba najbliższa ofiary pobicia, która od czasu przestępstwa jest nieprzytomna i bez kontaktu, podczas gdy ma to prawo uczestnik bójki po meczu piłki nożnej.

Czy przynajmniej postępowania o kompensate przeprowadzane sa sprawnie? Niestety nie, trwały one bowiem od 7 miesięcy do 3,5 roku. Prokurator, skupiajaccy się na roli reprezentanta Skarbu Państwa zabiegał przy tym zwykle o niską rekompensatę. Szczególnie bolesne są przypadki, w których ofiarę przestępstwa mylnie informowano (czynił to organ państwowy), że rekompensaty finansowej w imieniu państwa udzieli jej Rzecznik Praw Obywatelskich. Gdy ofiara otrzymywała prawidłową informację co do trybu kompensaty, na złożenie wniosku było za późno. Analiza tej jednej ustawy pokazuje, jak wadliwe prawo może stać się dzisiaj źródłem dyskryminacji, podważać zaufanie obywateli do państwa, naruszać zasady sprawiedliwości społecznej i techniki legislacyjnej.

\section{IV}

Czy ogólne rozluźnienie rygorów legislacyjnych może wpłynąc dewastująco także ogólnie na cały system prawa i wymiaru sprawiedliwości? Przykładem może być sytuacja, w której dopuszczono - logicznie i wydawałoby się dla poprawy sytuacji podatnika - indywidualne interpretacje podatkowe. Nawet ok. $60 \%$ z nich jest jednak uchylanych, a niepewność pogłębił brak jednolitości orzecznictwa. To dodatkowo napędza dążenie do dalszych indywidualnych interpretacji. W orzecznictwie NSA w ok. 40\% to już właśnie sprawy podatkowe, co z kolei lawinowo pogarsza stan obciążenia sądów ${ }^{40}$. Stanowienie prawa w tej sytuacji traci swój finalny, a przez to całościowy charakter, staje się raczej zaproszeniem do negocjacji, niewłaściwym $\mathrm{w}$ tej sytuacji rodzajem jakiegoś soft law, dostępnego zwłaszcza dla lepiej obeznanych w prawie podatników.

40 Zob. R. Mastalski, Wpływ orzecznictwa na stosowanie prawa podatkowego, „Ruch Prawniczy, Ekonomiczny i Socjologiczny” 2011, z. 2; R. Wiatrowski, Istota i charakter prawny tak zwanej milczacej interpretacji podatkowej, „Ruch Prawniczy, Ekonomiczny i Socjologiczny” 2009, z. 3; Z. Kmieciak, Przewlekłość postepowania administracyjnego w świetle ustaleń europejskiego case law, w: Analiza $i$ ocena zmian Kodeksu postepowania administracyjnego w latach 2010-2011, Wyd. NSA, Warszawa 2012. 
Wśród dysfunkcji zdarzają się nawet nowelizacje jeszcze przed wejściem ustawy w życie (przy braku wyciagania konsekwencji wobec osób odpowiedzialnych za to niesłychane naruszenie zasad legislacji $\left.{ }^{41}\right)$. Rola posła sprawozdawcy nie łączy się już w przekonaniu klubów poselskich z odpowiedzialnością za legislacyjną nienaganność tekstu, jest raczej zobowiązaniem do lojalnego przedstawienia stanowiska komisji. Poprawki nadal nie maja swoich jawnie wymienionych autorów, co sprzyja poczuciu bezkarności za ich treść i patologii lobbingu. Szybkość tworzenia prawa staje się ważniejsza niż jego jakość.

Z kolei przyczynienie się do powstania prawa wysokiej jakości nie jest już znaczacym elementem zawodowego sukcesu posła, znajduje odbicie praktycznie tylko w niektórych rankingach dziennikarskich ${ }^{42}$. Mimo ostrzeżeń Biura Legislacji i Biura Analiz Sejmowych ${ }^{43}$, przechodza projekty sprzeczne z podstawowymi zasadami techniki legislacyjnej i zasadami stanowienia prawa - powszechnie przyjętymi w doktrynie prawa oraz wspólnymi dla dziedzictwa ius publicum Europaeum ${ }^{44}$. To poczucie „rozluźnienia” może wynikać ze słabnącej roli prezydium Sejmu i przewodniczących komisji. Brak także stałego monitorowania funkcjonowania całości systemu prawa, choć prowadzone sa badania naukowe nad jego jakością. Wychwycone przez Sąd Najwyższy strukturalne nieprawidłowości nie przekładają się na szybkie inicjatywy legislacyjne. Istnieją też wciąż, częściowo wskazane już wyżej" ${ }^{45}$ zdumiewające zaniedbania $\mathrm{w}$ procedurze, prawie materialnym i ustroju nieusuwane od lat.

Czy te zaniedbania polskiej legislacji pozostaja niezauważone? Jak wskazuje alarmujacco po analizie tych słabości Wiesław Staśkiewicz, 85\% badanych respondentów wskazuje na „niewielki autorytet” Sejmu - co jest znaczącym pogorszeniem wskaźników w stosunku do tych z początków naszej 25-letniej niepodległości. Często przypisuje się jednak taką utratę autorytetu parlamentu „przesunięciu funkcji” pod wpływem europeizacji i coraz większemu znaczeniu prawodawcy europejskiego. Staśkiewicz wykazuje jednak na podstawie badań, że istnieją już instrumenty pozwalające prawidłowo wykonywać zadania parlamentu również w tej nowej roli, a ustawa o współpracy rządu w stosunku do Sejmu i Senatu w sprawach Unii Europejskiej jest ukształtowana wystarczajaco ${ }^{46}$. Przykładowo Marszałek Sejmu kieruje niezwłocznie do

41 Pogląd ten podziela TK, który w swoim wyroku wskazuje: „Negatywnie oceniana jest praktyka legislacyjna polegająca na zmianie przepisów po podaniu do publicznej wiadomości w sposób formalny ich treści, a przed ich wejściem w życie”, wyrok z 18 stycznia 2005 r., K 15/03, zob. więcej w: Proces prawotwórczy w świetle orzecznictwa Trybunału Konstytucyjnego, Warszawa 2013.

${ }^{42}$ Zob. http://www.polityka.pl/kraj/1556381,1,ranking-poslow-polityki-rozstrzygniety.read.

${ }^{43}$ P. Radziewicz, W. Staśkiewicz, Analiza prawna jakości legislacyjnej rzqdowych projektów ustaw przygotowanych w latach 2011-2012, Materiały BAS.

${ }^{44}$ S. Wronkowska, Tworzenie prawa w Polsce - ocena i proponowane kierunki zmian. Raport Rady Legislacyjnej przy Prezesie Rady Ministrów, „Przegląd Legislacyjny” 2006, nr 1 (53), s. 7 i n., a także eadem, Zasady przyzwoitej legislacji $w$ orzecznictwie Trybunału Konstytucyjnego, w: M. Zubik (red.), Księga XX-lecia orzecznictwa Trybunału Konstytucyjnego, Warszawa 2006.

45 Zob. System stanowienia prawa w Polsce. Zielona Ksiega, Warszawa 2013, wydana przez Kancelarię Prezydenta RP, a także P. Gryska, Rola Rzqdowego Centrum Legislacji w wykonywaniu wyroków Trybunału Konstytucyjnego, w: K. Budziłło (red.), Księga XXV-lecia Trybunału Konstytucyjnego, Warszawa 2010.

${ }^{46}$ W. Staśkiewicz, Wpływ polskiego ustawodawcy na porzadek prawny RP. Sejm wobec prawa UE 10 lat później, prezentacja z materiałów pokonferencyjnych, Wydział Prawa i Administracji Uniwersytetu Warszawskiego. 
Komisji informację Rady Ministrów o stanowisku RP, jakie Rada Ministrów ma zamiar zająć podczas rozpatrywania projektu w Radzie wraz z uzasadnieniem tego stanowiska i oceną skutków prawnych, społecznych, gospodarczych i finansowych dla $\mathrm{RP}^{47}$.

Ubytek starych funkcji rekompensują nowe, ponadto przedkłada się projekty umów, których stroną ma być Unia Europejska, i projekty decyzji przedstawicieli innych rządów zebranych w Radzie oraz 10 innych rodzajów projektów strategicznych rozstrzygnięć. Komisja, zwłaszcza ds. Unii Europejskiej, może odgrywać ogromną rolę w wypracowywaniu polskiego stanowiska i monitorowaniu stanowiska innych krajów - członków Unii Europejskiej. Czy wykorzystujemy tę szansę? Rotacja w Komisji ds. Europejskich jest bardzo wysoka. Analiza aktywności Komisji wskazuje często na zawężenie szerokich uprawnień. Ukazane dysfunkcje legislacyjne powinny być skutecznie zwalczane przez organy Sejmu.

Rosnaca rola prawa europejskiego nie stanowi więc wystarczającego wyjaśniania kryzysu legislacji, który przekłada się na problemy dyscyplin szczegółowych. Nieprzypadkowo ostatni Zjazd Katedr Prawa Administracyjnego nosił właśnie tytuł „Kryzys prawa administracyjnego w administracji publicznej" ${ }^{48}$. Niespójne prawo, źle przygotowane i chaotycznie zmieniane nie może dawać poczucia bezpieczeństwa obywatelom, generując niepewność co do ich obowiązków nie tylko podatkowych. Jeżeli takie prawo jest wymieniane przez przedsiębiorców, mimo kryzysu finansowego, jako jedna z głównych barier rozwoju gospodarczego, to stanowi to istotną informację dla podmiotów rządzących krajem. Brak postlegislacyjnej oceny skutków regulacji (OSR) i w ogóle brak obowiązku tworzenia OSR wobec projektów poselskich stanowi ważne źródło dysfunkcji stanowienia prawa ${ }^{49}$. Skoro zaś projekty poselskie stanowią ok. $50 \%{ }^{50}$ projektów, to oznacza, że dobrowolnie wyzbywamy się efektywnej kontroli jakości prawa wobec licznych aktów. Rzecznik Praw Obywatelskich co prawda dokonuje - głównie w wystapieniach generalnych postlegislacyjnej OSR z punktu widzenia praw człowieka, co doceniono w Zielonej księdze, ale pozostaje w tym zakresie osamotniony. Wzmocnienia wymaga pod tym względem także wykorzystywanie raportów NIK do wniosków postlegislacyjnych.

\footnotetext{
${ }^{47}$ Art. 148b Regulaminu Sejmu.

${ }^{48}$ Zjazd Katedr Prawa Administracyjnego i Postępowania Administracyjnego w dniach 23-26 września 2012 r. odbył się na Uniwersytecie w Białymstoku. Efektem zjazdu jest czterotomowa publikacja: t. 1: Jakość prawa administracyjnego, red. D. R. Kijowski, A. Mikuć, A. Suwałko-Kawałko; t. 2: Inflacja prawa administracyjnego, red. P. J. Suwaj; t. 3: Wypieranie prawa administracyjnego przez prawo cywilne, red. A. Doliwa, S. Prutis; t. 4: Wyktadnia $i$ stosowanie prawa administracyjnego, red. D. R. Kijowski, J. Radwanowicz-Wanczewska, M. Wincenciak, Wolters Kluwer, Warszawa 2012.

${ }^{49}$ Zob. System stanowienia prawa w Polsce. Zielona Ksiega, Warszawa 2013, http://www. prezydent.pl/download/gfx/prezydent/pl/defaultaktualnosci/2375/26/1/fdp_zielona_ksiega.pdf; Choć działania BAS należy docenić, nie ma ono środków ani kompetencji na sporządzanie takich ocen skutków regulacji ekonomicznych i społecznych o kompleksowym charakterze.

${ }^{50}$ Zob. M. Żuralska (red.), Analiza działalności ustawodawczej Sejmu VI kadencji, Warszawa 2012.
} 
Sprawiedliwość społeczna, na straży której ma stać Rzecznik Praw Obywatelskich, odróżnia Rzecznika od innych organów ochrony prawnej. Czym jest owa sprawiedliwość, jak mógł ją rozumieć ustrojodawca i jak RPO może realizować ów konstytucyjny nakaz? W przypadku „stania na straży prawa" można brać za wzór inne państwowe organy kontroli - jak Najwyższa Izba Kontroli - i organy ochrony prawnej. W przypadku RPO realizuje się to w sposób oczywisty przez skargi kasacyjne do Sądu Najwyższego i skargi do Naczelnego Sądu Administracyjnego, wnioski do Trybunału Konstytucyjnego oraz przez wystapienia do ministrów i wystapienia przed TK, SN i NSA. Wszystko to zostało dobrze opisane w literaturze przedmiotu ${ }^{51}$. Jak jednak dbać o sprawiedliwość społeczną i strzec jej, nie wpadając w rolę polityczna, której Konstytucja Rzecznikowi wyraźnie zakazuje? Jest w tym przecież pozorna sprzeczność: zasadniczym „wprowadzeniem” sprawiedliwości społecznej zajmują się parlamenty i rządy, stanowiąc prawo, chyba że działają w skrajnej, liberalnej formie i rozumieniu sprawiedliwości społecznej w wersji von Hayeka, odrzucając samo to pojęcie ${ }^{52}$. Wydaje się to więc na pierwszy rzut oka raczej działaniem politycznym, a jednak ma być treścią apolitycznych działań każdego Rzecznika. Oznacza to dyrektywę kontroli władzy publicznej i wszystkich jej aktorów pod kątem realizacji tej specyficznej postaci dobra wspólnego, jednak bez narzucania konkretnego kształtu polityce publicznej. Bardziej chodzi o monitorowanie sposobu osiagania celów społecznych i konstytucyjnych standardów regulacji oraz proporcji alokacji środków publicznych przez piętnowanie rażącego naruszenia sprawiedliwości społecznej.

Czy sprawiedliwość społeczna nie pozostała ogólnikową deklaracją konstytucyjną? Czy Trybunał Konstytucyjny korzystał w ogóle w swoim orzecznictwie z tego kryterium po roku 1989? Należy to ostatnie potwierdzić - już 22 sierpnia 1990 r. pojawiło się, w nawiązaniu do zasady demokratycznego państwa prawnego, zalecenie, aby „zróżnicowanie poszczególnych ludzi pozostawało w odpowiedniej relacji do sytuacji tych ludzi”53. Historyczne było także wyrażenie, że „rdzeniem sprawiedliwości jest bezstronność”. Już w 1990 r. Trybunał Konstytucyjny uznał sprawiedliwość społeczną za „nadrzędną wartość systemu prawa" ${ }^{54}$, jednakże w 1998 r. ograniczył jej znaczenie, stwierdzając, że: „klauzula sprawiedliwości społecznej nadaje się do stosowania przede wszystkim, jako argument dodatkowo uzasadniający fakt naruszenia określonej bardziej konkretnej normy czy zasady konstytucyjnej. Tylko natomiast

${ }^{51}$ Zob. S. Trociuk, Rzecznik Praw Obywatelskich. Komentarz, Lex, nr 7699, 2007 r.; K. Nalaskowski, Sposób wykorzystania kompetencji przez Rzeczników w latach 1987-2007. Opracowanie, w: M. Zubik (red.), op. cit., t. 4, s. 151 i n.; Informacja o działalności Rzecznika Praw Obywatelskich w roku $2012 \ldots$, passim.

${ }^{52}$ Zob. R. Pyka, Globalizacja-sprawiedliwość społeczna-efektywność ekonomiczna. Francuskie dylematy, Wyd. UŚ, Katowice 2008, s. 26.

${ }^{53}$ K 7/90, OTK ZU 1989-1990, t. 2, s. 202.

${ }^{54}$ K 12/90, OTK ZU 1989-1990, t. 2, s. 210-217. 
w wyjątkowych sytuacjach może ona występować jako samoistna i wyłączna przesłanka do wydania orzeczenia o niekonstytucyjności” ${ }_{55}$. To zdecydowane osłabienie pierwotnego stanowiska TK ${ }^{56}$, z którym trudno się w płaszczyźnie teoretycznej zgodzić - choć ważne, że Trybunał dopuszcza istnienie „sytuacji wyjątkowych” - określiło na lata drugorzędną rolę zasady sprawiedliwości społecznej w systemie ochrony praw i wolności. Pora na ponowne przemyślenie tego podejścia w kontekście 25 lat doświadczeń ustrojowych.

Sprawiedliwość społeczna jako zasada ustroju i działanie nadaje się do przełożenia na praktykę działania samorządu terytorialnego i administracji rządowej, ale nie jest to od lat właściwie, konsekwentnie czynione. Brak preambuł, określania celów ustawy - np. w przypadku przeciwdziałania bezdomności, ochrony zdrowia, utrudnia właściwe ukierunkowanie całościowego działania administracji. Dzisiaj nawet całkowite zaniechanie pewnych funkcji (np. budowy mieszkań komunalnych czy schronisk dla bezdomnych rodzin) jest w istocie bezkarne i pozostaje poza zakresem nadzoru nad samorządem terytorialnym. Można rozważać np., czy brak programu przeciwdziałania bezdomności nie stanowi takiej „wyjątkowej sytuacji” z zakresu sprawiedliwości społecznej, skoro w okresie zimowym co roku, i to od wielu lat, umiera w Polsce do 200 bezdomnych osób.

Zygmunt Ziembiński ${ }^{57}$ nie traktował zasady sprawiedliwości społecznej jako „prawdziwej” zasady prawnej, stawiając ją raczej na równi z zasadami współżycia społecznego. W odróżnieniu od zasad współżycia społecznego odnoszących się głównie do stosowania prawa, zasady sprawiedliwości społecznej mają odnosić się głównie do stanowienia prawa, ale - jak wskazuje autor pojawiająca się argumentacja jest zazwyczaj „zdawkowa”. Brak, co podkreśla Ziembiński, „nawet w literaturze prawniczej z zakresu polityki prawa i dyscyplin szczegółowych, zarysowania ogólnego toku argumentacji w tych sprawach”. Należy zgodzić się z autorem i podkreślić, że sytuacja w literaturze nie zmieniła się w tym zakresie zasadniczo mimo upływu wielu lat od 1996 r., kiedy to autor formułował ten pogląd. W szczególności trudno - na podstawie przeglądu literatury - stwierdzić, która formuła sprawiedliwości (np. wyrównawczej) jest dziś powszechnie przyjęta. Synkretyzm i „zamęt semiotyczny” argumentacji są dość powszechne, a „zdawkowość argumentacji” często spotykamy nadal np. na posiedzeniach sejmowych uzasadniajacych ogólnikowo projekt dowolnej ustawy sprawiedliwościa społeczna. Istnieje potrzeba nowej debaty publicznej nad pojęciem sprawiedliwości społecznej. Zamęt, nie tylko semiotyczny, ale i aksjologiczny w tej kwestii utrudnia osiagnięcie konsensusu w tak ważnych kwestiach, jak np. zasięg i zasady reprywatyzacji w Polsce czy obowiązki samorządu w kwestii budowy mieszkań komunalnych, co mogłoby

${ }^{55}$ K 12/98, OTK ZU 1998, nr 6, poz. 98, s. 538-549.

56 J. Karp, Sprawiedliwość społeczna. Szkice ze współczesnej teorii konstytucjonalizmu i praktyki prawa ustrojowego, Księgarnia Akademicka, Kraków 2004, s. 190-191.

${ }_{77}$ Zob. Z. Ziembiński, Doktryny sprawiedliwości $i$ ich konsekwencje prawnopolityczne, oraz Zasady sprawiedliwości społecznej a zasady prawa w: Sprawiedliwość społeczna jako pojęcie prawne, Wydawnictwo Sejmowe, Warszawa 1996. 
ograniczyć masową emigrację ludzi młodych. Dopiero konsekwencją tego stanu są luki w regulacji, zdumiewajacca jej niespójność lub „milczenie władzy” w kwestiach systemowych (bezpłatna pomoc prawna), a nie tylko jednostkowych $^{58}$.

Po 25 latach można już uwolnić - w moim przekonaniu - tę debatę od balastu pojęć sprawiedliwości społecznej PRL, czerpiąc jednak wnioski z popełnionych wówczas błędów. Jak wskazuje Artur Laska ${ }^{59}$, w okresie transformacji, którą kończymy, istnieje naturalny stan „instytucjonalnego zawieszenia”, w którym chwieją się lub nie obowiązują ani stare, ani nowe reguły, a docelowe rozwiązania sa niezrozumiałe. Rolę integrująca - wskazuje autor - odgrywaja wtedy idee polityczne, takie jak sprawiedliwość społeczna, które maja jednak ściśle określony kontekst historyczny. Należy zgodzić się z tym poglądem, jak również ze wskazaniem, że PRL nie tyle - wbrew deklaracjom - zrównywał obywateli w imię sprawiedliwości społecznej, ile zmieniał źródło tych nierówności. Powszechne poczucie niesprawiedliwości tamtego okresu, jak wskazuje Winicjusz Narojek ${ }^{60}$, pochodziło z konieczności całkowitego podporządkowania się celom systemu dla uzyskania indywidualnego powodzenia. Powstała nowa nierówność szans implikowana politycznymi kryteriami selekcji społecznej.

Realizowany wówczas model relacji społeczno-ekonomicznych diametralnie odbiegał od oficjalnie deklarowanych założeń normatywnych, a indywidualna inicjatywa była często karana, a nie nagradzana. Zmiana ustroju nie zniosła jednak potrzeby sprawiedliwości społecznej, o czym najlepiej świadczy przyjęcie jej za zasadę konstytucyjną III RP. Trafiliśmy jednak w trudne lata dziewięćdziesiąte - w Europie Zachodniej oznaczały one odwrót od materialnej do proceduralnej zasady sprawiedliwości. W podejściu Johna Powella czy Normana Tebbita ${ }^{61}$ było to równocześnie odrzucenie instytucjonalizacji sprawiedliwości społecznej, a co za tym idzie - państwa opiekuńczego jako państwa o mocnej pozycji administracji świadczącej. Polska debata publiczna nie została doprowadzona do końca: nie ma zgody co do tego, czy tak wielka skala nierówności w Polsce jest przejawem pożądanej różnorodności czy niesprawiedliwości. Dopiero ustalenie dominujących przekonań w tej kwestii „uruchomi" presję społeczną na legislację i orzecznictwo. Egalitaryzm polskiego społeczeństwa skłaniać go będzie zapewne do większego nacisku na realizację konstytucyjnej zapowiedzi dążenia do sprawiedliwości społecznej.

${ }^{58}$ Zob. więcej „Debaty Jana Nowaka Jeziorańskiego. Rozmowy o wartościach”, Biuro RPO, Warszawa 2013.

${ }_{59}$ A. Laska, Determinanty interpretacji sprawiedliwości społecznej $w$ dyskursie zmiany systemowej, w: Sprawiedliwość społeczna w dyskursie polskiej zmiany systemowej, Toruń 2011, s. 81 i n.

${ }^{60}$ W. Narojek, Socjalistyczne 'welfare state'. Studium z psychologii społecznej Polski Ludowej, Warszawa 1991, s. 16.

${ }^{61}$ A. Laska, op. cit. 


\section{VII}

Reasumując: nieoczekiwanym, poważnym źródłem naruszeń praw i wolności człowieka stał się po latach, mimo wielu osiagnięć, stan naszej legislacji, i to zarówno - jak wskazano w przykładach - w płaszczyźnie materialnej, jak i proceduralnej. Zmiany wymaga więc, w moim przekonaniu, nie tylko Regulamin Sejmu, ale i silniejszy niż dotąd nadzór organów parlamentu i rządu nad jakością stanowionego prawa. Powrotu do fundamentalnej dyskusji wymaga kwestia sprawiedliwości społecznej i jej odzwierciedlenia w prawie stanowionym, diagnozowana jako „wielka nieobecna” debaty publicznej i założeń legislacyjnych.

dr hab. Irena Lipowicz

Profesor Uniwersytetu Kardynała Stefana Wyszyńskiego

oraz Rzecznik Praw Obywatelskich RP

i.lipowicz@uksw.edu.pl

\section{THE CONDITION OF HUMAN RIGHTS PROTECTION FROM THE OMBUDSMAN'S PERSPECTIVE}

Summary

The article poses a question about the condition of human rights protection in Poland twenty-five years after regaining independence, seen from the perspective of the Ombudsman and after over sixty thousand complaints filed by Polish citizens every year.

The overall assessment is rather negative - despite numerous achievements of the first years after transformation, a certain 'loosening of the legislative standards' has recently been observed in the procedural, the systemic, and substantive-legal spheres, as illustrated with examples (e.g. the state compensation). This state of affairs is in contradiction to the constitutional rule and requires an immediate change; thus basic prerequisites for improvement of this condition have been identified. In the final section of the article much attention is paid to the analysis of inadequate realisation of the rule of social justice, safeguarded by the Ombudsman in the name of law.

The article ends with a conclusion that it is necessary to free the notion of social justice from the historical burden and restore its first and foremost role in human rights protection. Last but not least, a need is indicated for a stronger control over the government and parliament regarding the quality of the applied law. 
Copyright of Journal of Law, Economics and Sociology is the property of Faculty of Law and Administration of Adam Mickiewicz University in Poznan and its content may not be copied or emailed to multiple sites or posted to a listserv without the copyright holder's express written permission. However, users may print, download, or email articles for individual use.

Właścicielem praw autorskich do „Ruchu Prawniczego, Ekonomicznego i Socjologicznego” jest Wydział Prawa i Administracji Uniwersytetu im. Adama Mickiewicza w Poznaniu. Zawartość czasopisma nie może być kopiowana, przesyłana do innych stron internetowych bądź zamieszczana na blogach bez pisemnej zgody wydawcy. Niemniej artykuły można drukować, kopiować lub przesyłać w formie elektronicznej na własny użytek. 